\title{
MODEL OF A REGIONAL CLUSTER AS AN EXAMPLE OF THE CONCEPT FOR THE DEVELOPMENT OF THE REGION
}

\section{KRYSTIAN DĘBSKI}

\begin{tabular}{|c|c|}
\hline & $\begin{array}{l}\text { University of Gdańsk } \\
\text { e-mail: krystian_debski@tlen.pl }\end{array}$ \\
\hline $\begin{array}{l}\text { RECEIVED } \\
\text { ACCEPTED }\end{array}$ & $\begin{array}{l}16 \text { June } 2015 \\
1 \text { August } 2015\end{array}$ \\
\hline JEL & \\
\hline CLASSIFICATION & D83, R11, R58 \\
\hline KEYWORDS & $\begin{array}{l}\text { regional cluster, regionalization, regional competitiveness growth, strategy of region management, main factors } \\
\text { of functioning regional cluster, functioning model of regional cluster }\end{array}$ \\
\hline ABSTRACT & $\begin{array}{l}\text { Increasing the competitiveness of a region has a significant impact on improving the quality of inhabitants' } \\
\text { life. A perfect example of a concept that relates to this idea is a regional cluster. It is the concept specific for } \\
\text { regions considered as smart environments, based on business affiliation with academic institutions and crea- } \\
\text { tion of a network of mutual relations to facilitate information flow. Cooperation between participants involved } \\
\text { in regional clusters, their mutual contact, carrying out joint studies, research and projects are key elements } \\
\text { determining the connections between them. Their relationships are an excellent example of a properly function- } \\
\text { ing competition. Cluster initiatives intensify the implementation of innovation in the economy, thus leading to } \\
\text { a long-term economic success of the companies participating in the cluster and stimulate participating regions' } \\
\text { economic growth. The economic phenomenon of a free market competition and complex processes of resource } \\
\text { flows, that occur at the regional scale, force local authorities to analyze their management strategies and risk of } \\
\text { informed decision-making. Such strategy should be based on creating clusters and integrating them with exist- } \\
\text { ing processes and regional innovation strategies. The prospect of potential benefits from implementing cluster } \\
\text { initiatives encourages companies and local authorities to implement cluster friendly policies. }\end{array}$ \\
\hline
\end{tabular}

\section{Introduction}

Increasing the competitiveness of the region has a significant impact on improving the inhabitants' quality of life. New jobs, modern infrastructure and broader investment are aspects that have a direct impact on the attractiveness of the region. It should be emphasized, that economic status, which is closely linked to the attractiveness of the 
region, it is important, not only for us, but also for future generations. An example of an initiative that has a direct relationship with the development of the region are clusters.

The rationale for writing this article is that the literature does not sufficiently represents the essence of the cluster functioning, which is based on the competition in a particular region by associated companies cooperating with research centers. This entity is part of a broader idea of the concept of regionalization, consequently leading to changes in the region. In Poland the emergence of the concept of clusters could be observed over the last decade. Association as referred occurs within a specific economic region, and is supported by the local authorities. Companies which belong to the cluster simultaneously cooperate and compete with each other in order to create a common information system synergy. In this system, there is a transfer of data from scientific research centers to firms in the cluster. This action leads to increased competitiveness of the region, among others, through

- networking between businesses,

- creating favorable conditions for foreign investment,

- promoting innovation and new technologies,

- providing training,

- providing logistical support for businesses,

- branding of the region, etc. (Ketels et al., 2006).

Listing the growth factors of competitiveness of the region in terms of many emerging clusters, be aware of the prestige of local economies which create existing clusters. The fact is, that numerous well-functioning businesses associations with the scientific community are mainly found in highly developed economies. Clusters are a determinant of well-functioning local authorities and high public awareness. The regional nature of the clusters is directly related to the increase of competitiveness of the region. The objective of territorial integration in this case is obvious, because competitiveness depends not only on internal factors of the company but also from the external environment, effectively functioning social economies system in particular region can be included to the external environment, which are undoubtedly clusters (ed. Olszewska, 2007). The phenomenon of regionalization is therefore important in terms of the idea of clusters, which should be discussed in detail. The aim of the article is to present the essence of the functioning of the cluster as a concept of increasing the competitiveness of the region. Using inductive deductive scientific method, like for instance an examination of the mechanism of the cluster, and by verification of the operation of the above-mentioned research hypothesis.

\section{The essence of economic regionalization as a foundation for the operation of the cluster}

A key issue when considering the phenomenon of economic regionalization as the foundation of the cluster, is to determine the difference between physical-geographical region and economic region. Definition of physical-geographical region reads as follows: "The area to which the different parts have as many features in common, and show as many differences in relation to neighboring areas" (Berezowski, 1964). However, if the region is tested in terms of competitiveness or other economic characteristics, it is without a doubt the economic region. This theorem leads to the definition of the economic region as an area that stands out from neighboring areas in economic terms. Therefore the concept of economic regionalization should be understood as a procedure of division of particular areas into economic regions, id est smaller and relatively homogeneous areas, forming some kind of economic integrity due to the economic criteria adopted (Baczwarow, Suliborski, 2002). Regionalization of the world is carried out based on the following categories id est the distribution of economic and social activity, the interaction between 
the states and the interaction between groups of countries. People who interpenetrate these three criteria can claim that they have a common cause, which are the processes of economic, social, cultural and political. Observing the spatial interaction between people, companies and regions can be seen, that their impact is inversely proportional to the distance. The size of flows between companies depends on the size of the economic centers (Domański, 2004). The economic consequences of the listed statements motivated to present an outline of the historical category of economic regionalization.

The importance of economic regionalization category, as well as the historical context allows to refute the thesis of freedom of enterprise, in terms of their regional location (ed. Klasik, 2002). Examining regional economy and its development can be found already in the works of classics of economics. They expressed the view that any economic study on the deployment and product development must take into account properly understood the diversity of economic conditions in different geographical regions (Berezowski, 1964). Neoclassical s position was the same. A. Marshall in the work of 1890 entitled "Principles of Economics", described the concept of "economic district", as a regional cluster of enterprises of one industry. According to Marshall, enterprises belonging in the region to cluster drew the benefits of geographical proximity and mutual relations between enterprises (Gorynia, Jankowska, 2008). The economic aspect of regionalization and the effects of geographic location of companies were also analyzed in the publication written by American economist ME Porter. The study titled "The Competitive Advantage of Nations", promoter of clusters, as talked about, introduced the theory of national and regional competitiveness based on factors, like geographical location of companies and sectors. The theory is based on the results of studies conducted in ten highly industrialized countries of the world (Leśniewski, 2012). The economic aspect of regionalization is the source of the concept for management of changes in the region, which are discussed in the next section.

Analysis of economic areas from the angle of economic indicators shows that in particular regions of European countries there are clear differences between them. Developed regions and underdeveloped, otherwise the disparities between them are a problem in many countries including Poland. In order to solve this problem, efforts are underway to increase the competitiveness of the region. In Figure 1 shows an actual management of changes strategies in the region.

\begin{tabular}{|c|c|c|}
\cline { 3 - 3 } \multicolumn{1}{c|}{$\begin{array}{c}\text { RESTRUCTURING } \\
\text { - get rid of the past } \\
\text { DIVERSIFICATION }\end{array}$} & $\begin{array}{c}\text { REVITALIZATION } \\
\text { - Discovering } \\
\text { the future. } \\
\text { CREATING A NEW } \\
\text { QUALITY REGION }\end{array}$ \\
\hline & CHANGE & \\
\hline \multirow{2}{*}{ MANAGEMENT } \\
MANAGEMENT \\
OF DAMAGE \\
- Old has value \\
CONTINUE
\end{tabular}

Figulp 1. Change management strategies in the region

Source: Olesiński (2005): 99. 
According to the concept shown in Figure 1, there are two main approaches to the management of changes in the region. The first approach is to restructure, and therefore, improving existing processes (left side of the Figure). The second approach is to implement new solutions in the region (right side of picture). It should be emphasized that the new solutions through the use of scientific research and new technologies will help create a more efficient and adapted to the current conditions of regional management process. Creating value from scratch is always associated with a high risk, but the benefits of its efforts to promote innovation, coupled with the support of local entrepreneurship is a key element in building a competitive advantage in the region. As part of the management of changes strategy in the region consisting of innovation management, there are many initiatives, among which the special attention deserved - clusters. As has already been articulated, they are business association concerned and operated within the boundries of the region and research centers supported by the local authorities. The main aim of the clusters is to promote the growth of competitiveness of the region through the transfer of knowledge from research centers to enterprises. According to the course of argument, a model of how cluster is functioning should be presented as a cluster scheme implemented to measures and increase the competitiveness of the region.

\section{Operation model of the cluster}

Observed the existence of many clusters forms and individualism of these specific associations is dependent on the economic reality in which they operate, we adopt the organizational forms, the industry in which they operate, etc. The major types of clusters include the following:

- network,

- concentric

- institutional.

Networked Clusters create small businesses. The subject of their activities is the same or similar branch of production. They are characterized among others by, the ability to quickly adapt to changes in sourroundins, broad access to the local market and low costs. In clusters of concentric dealing with small companies concentrating primarily on suppliers around the large companies, which are usually their big business partners. The last type are institutional clusters that bring together public entities such as research and development laboratories, universities, state, public administration and so on (ed. Stabryla, 2009). The key issue in terms of the proper functioning of the cluster is the phenomenon of competition between its members. Word of competition in the Polish language is derived from the Latin phrase concurrere, which can be translated as run together. English-speaking authors as a origin of the word competition give us a Latin phrase cum Peter, which means the joint search. Etymological origin of the word competition in both Polish and English competition is something that is jointly exercised or sought after. Assuming the above considerations it can be concluded that competition should indeed be a common search for a solution, a compromise, that each of the parties use to pursue their goals. Demand side because it meets their needs at a satisfactory level, and the supply side because it is the recipients of its products and services, who are willing to pay a certain price for a certain quality. The reality is different. Competitors often boils down to competition between rivals in the market, which in turn can lead to devastating competition between companies which are competing with each other (Stankiewicz, 2006). The concept of competitiveness in the region is variously defined . Regions can compete in terms of: cost, range, product quality, innovation, foreign investment, etc. Among the factors determining the competitiveness of the region in recent years, most attention is attributed to the wider ability to institutional and intangible factors that stimulate innovation in the region. This leads to the process of collective 
education and synergies, id est: "interaction resulting in a certain effect" (Mańkowski, 2009). Such a way to compete with the regional high road of development and classifies the region to "smart" (Region intelligent). The essence of this region is the existence of the creative process - specific resources, thanks to dense networks of relationships associated with the proximity of the location. The opposite kind of competition is a competition based on low costs, associated with improperly paid labor force - The "way low" (ed. Klasik, 2002).

A perfect example of a regional initiative which enrolls into competition model - based on the high road development in the region which is a cluster. It is a concept characteristic of intelligent regions. Affiliation is based on business communities with scientific institutions and creating a network of mutual ties in order to ensure an uninterrupted flow of information. Here are the types of so-called. ties, network connections occur in clusters:

- synergy,

- affiliate,

- friendly,

- of a competition (Olesiński, 2005).

The fact that the cooperation between participants clusters and implying their mutual contact by conducting joint studies, research and projects is consequently the cause of existence between the two network connections. This is an excellent example of a correctly functioning competition between them, in accordance with the Latin phrase concurrere - "run together". In order to fully understand the essence of cluster operations, as well as the changes taking place in the region as a result of numerous emerging clusters, provide a model of operation. In clusters we have to deal with a specific chain of organizations with mutual dependencies. The new chain organization generates synergies on many levels, and is the essence of a cluster. By examining the relationship between the size of the investment and production in growth can be demonstrated if the increment size has an effect on the generation of synergy. In clusters with similar outlays in the framework of cooperation with other participants increases, should be undoubtedly higher. This happens because the model of the cluster provides an increase in competitiveness of the region as a result of the business environment continued cooperation with research centers. Accordingly, the characteristics of the model should be provided within clusters which realize their assumptions.

In order to fully understand the mechanism of functioning of the cluster and its impact on the growth of competitiveness of the region, a model of its functioning was created. Model of functioning is based on three leading factors:

- aspect of social, political and economic,

- the objectives of cluster initiatives,

- the process of functioning of the cluster (Ketels et al., 2006).

The social aspect involves broad social relations and partnership between: the companies operating in the cluster, government and research community. According to the political aspect, clusters are a tool of regional policy, while the role of regional policy depends on the policy of the country in which it occurs. Accordingly, the strength of the clusters determines role of regional policy. The economic aspect includes financing, as well as any cash flows that may occur during the operation of the cluster. In economies which are in transition or there are in developing process, the cause of the difficulties faced by clusters is the lack of funds for financing, but also all kinds of barriers like; administration - institutional. The second leading factor are cluster's goals that can be divided into:

- increasing the competitiveness and productivity of the region,

- supporting the expansion of clusters, 
- intensification of innovation and new technologies,

- education and training,

- research and networking between academia and business,

- involvement of local authorities in the development of the region,

- trade cooperation cluster members.

For these purposes, you can specify many groups, most of which are quoted in the introduction to this article.

The third factor is a model of the cluster initiative process . Cluster initiative process consists of the following elements:

- running cluster,

- management and financing,

- the scope of membership,

- resources and animator,

- frame (basic fundamental ) and common goals (agreement),

- momentum (Ketels et al., 2006).

Cluster initiatives are launched in different ways. The initiator, referred to as an animator, there may be one or more businesses, as well as national, regional or local. Clusters in countries such as Poland or Norway are not seen at the level of state policy, but regional policy. Therefore, the animators are usually local political organizations. An example of initiatives, that animators are local political organizations is the Food Cluster Initiative in Trondheim in Norway and initiative bearing the name of Lettmetall Total as aluminum cluster initiative in the region Raufoss in Norway. The administrative procedures are very complex and depends on the country in which the initiative was founded (Ketels et al., 2006).

The issue of cluster management depends on the entity, that is the animator id est a company branch or a local authority. Financing of cluster initiatives in highly developed countries such as the United States is realized through membership fees that replace government or industry start-up capital. Another element of the process is the range of the membership, it is specified in the status or the regulations of the cluster set of criteria that must be met by a member. For example, the Austrian Food Cluster initiative did not agree to join direct competitors. It was only possible to entry of companies that are not a direct threat to themselves because it would compromise their free establishment of the common information network Cluster Resources are all tangible and intangible assets necessary for the operation of the elements of its structure. Animator, usually whole organizer of functions and an adviser is supervised by the members themselves appointed by the Board of Directors. Fundamentals of the fundamental principles of the associations formed in the form of regulations, joint arrangements, as well as status. Clusters can also benefit from the arrangements already existing franchise organization process (Ketels et al., 2006). The last element of this momentum, which consists of marketing activities aimed at promoting initiative and its objectives as an idea for the development of the region and the entire economy.

Based on the adopted model of the factors leading cluster in Figure 2 presents its complete model. 


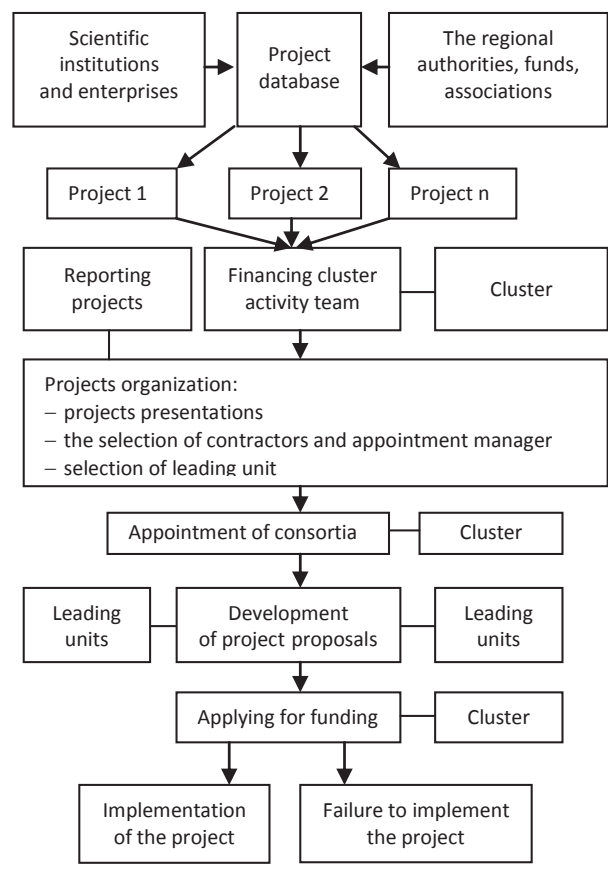

Figure 2. An exemplary model of the cluster

Source: Stabryła (2009): 72.

Figure 2 shows how scientific institutions in collaboration with companies generate projects, that are recorded in the database projects. Local authorities have access to the database and they can verify whether the project has the potential to incorporate the project into effect. Individual projects are also verified by the team. Finance cluster, which aims to examine the costs of its implementation, and the benefits from the implementation of a specific project. The next step is to organize projects by individuals notifying the project, and the establishment of a consortium of the cluster, which reports to the competent authorities for project financing. Depending on the decision on financing the project is implemented or rejected. A regional cluster model shows how companies in cooperation with research centers carry out joint projects, while competing with each other. Such actions are characteristic for intelligent regions and contribute to the competitiveness of the region.

\section{Conclusions}

Intensify the process of regional clusters of innovation in the economy, thus leading to long-term economic success of the participating companies the cluster and to the development of the region in which the initiative operates. The phenomenon of competition in a free market economy, and the complex processes of resource flows, that occurs on the regional scale forcing regional authorities to analyze the regional management strategies and decision-making at risk. One of them is the creation of cluster building processes and their integration processes and regional innovation strategies. The prospect of the potential benefits of cluster initiatives for companies and regions 
are encouraged by regional authorities to implement policies to promote clusters. The idea, which is dedicated to this article promotes the development activities in the region: increase competitiveness and productivity among regions through synergies and access to information, increase innovation through cooperation with scientific research centers, as well as joint projects, research and analysis, creation of new businesses by filling niches and expanding the boundaries of the cluster.

\section{References}

Baczwarow, M. \& Suliborski, A. (2002). Kompendium wiedzy o geografii politycznej i geopolityce. Warszawa: Polskie Wydawnictwo Naukowe.

Berezowski, S. (1964). Wstęp do regionalizacji gospodarczej. Warszawa: Wydawnictwo Szkoły Głównej Planowania i Statystyki.

Domański, R. (2004). Geografia Ekonomiczna. Warszawa: Polskie Wydawnictwo Naukowe.

Gorynia, M. \& Jankowska, B. (2008). Klastry a międzynarodowa konkurencyjność i internacjonalizacja gospodarki. Warszawa: Difin.

Ketels, C., Lindqvist, G. \& Solvell, O. (2006). Cluster initiatives in developing and transition economies. Stockholm: Stockholm School of Economics.

Klasik, A. (ed.) (2002). Konkurencyjność miast i regionów a przedsiębiorczość i przemiany strukturalne. Katowice: Wydawnictwo Uczelniane Akademii Ekonomicznej im. Karola Adamieckiego.

Leśniewski, M. (2012). Koncepcja klastra w kształtowaniu rozwoju regionalnego - ujęcie teoretyczne. Zarys problemu. Available as pdf (accesed on 15.05.2015).

Mańkowski, C. (2009). Synergia w logistyce. Gdańsk: Wydawnictwo Uniwersytetu Gdańskiego.

Olesiński, Z. (2005). Zarządzanie zmianami w regionie. Warszawa: Difin.

Olszewska, B. (ed.) (2007). Podstawy zarządzania przedsiębiorstwem na progu XXI wieku. Wrocław: Wydawnictwo Akademii Ekonomicznej im. Oskara Langego.

Stabryla, A. (ed.) (2009). Doskonalenie struktur organizacyjnych przedsiębiorstw w gospodarce opartej na wiedzy. Warszawa: C.H. Beck.

Stankiewicz, M. (2006). Konkurencyjność przedsiębiorstwa. Toruń: Wydawnictwo Atelier.

Kazimierski, J. (2010). Prokonkurencyjna polityka regionalna a rozwój klastrów logistycznych. Logistyka, 4: 16-19.

Cite this article aS: Dębski, K. (2015). Model of a regional cluster as an example of the concept for the development of the region. Szczecin University Scientific Journal, No. 883. Service Management, 16 (2): 19-26. 